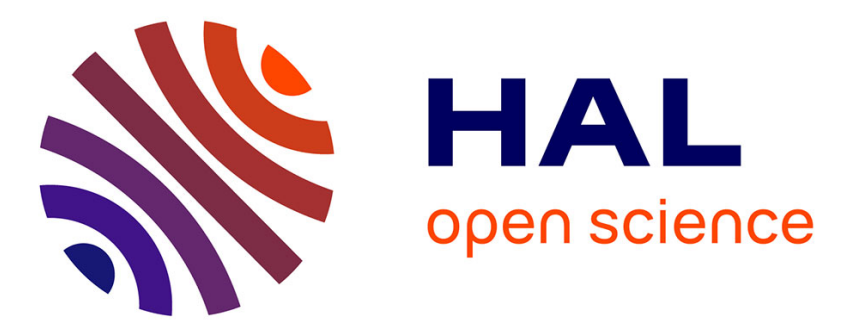

\title{
Supply Chain Optimization in the Tire Industry: State-of-the-Art
}

Kartika Nur Alfina, R. Ratnayake

\section{To cite this version:}

Kartika Nur Alfina, R. Ratnayake. Supply Chain Optimization in the Tire Industry: State-of-the-Art. IFIP International Conference on Advances in Production Management Systems (APMS), Sep 2019, Austin, TX, United States. pp.59-67, 10.1007/978-3-030-29996-5_7 . hal-02460494

\section{HAL Id: hal-02460494 \\ https://hal.inria.fr/hal-02460494}

Submitted on 30 Jan 2020

HAL is a multi-disciplinary open access archive for the deposit and dissemination of scientific research documents, whether they are published or not. The documents may come from teaching and research institutions in France or abroad, or from public or private research centers.
L'archive ouverte pluridisciplinaire HAL, est destinée au dépôt et à la diffusion de documents scientifiques de niveau recherche, publiés ou non, émanant des établissements d'enseignement et de recherche français ou étrangers, des laboratoires publics ou privés.

\section{(c)(1)}

Distributed under a Creative Commons Attribution| 4.0 International License 


\title{
Supply chain optimization in the tire industry: state-of- the-art
}

\author{
Kartika Nur Alfina $^{1}$ and R.M. Chandima Ratnayake ${ }^{2}$ \\ ${ }^{1}$ University of Indonesia, Depok, Indonesia \\ ${ }^{2}$ Department of Mechanical and Structural Engineering and Materials Science, University of \\ Stavanger, Stavanger, Norway \\ kartika.alfina@yahoo.com ; chandima.ratnayake@uis.no
}

\begin{abstract}
Recent research underlines the crucial role of supply chain optimization, in terms of maximize profit and minimize cost. Today the stakeholders are also empowered and the organizations are becoming stakeholder-centered, relates to the main objectives of a supply chain are availability and inventory control so the particular aim for availability must relate to stakeholder satisfaction. The implementation of supply chain optimization in tire industry nowadays not only focuses on profit, but also on the environmental and societal effect that is considered as ways to achieve the sustainable supply chain and stakeholder satisfaction. Currently a wealth of literature on supply chain optimization with maximize profit and minimize cost, to the best of our knowledge there is limited state-of-the art review on supply chain optimization considering with economy, environment and stakeholder satisfaction. This manuscript analyze research stream on supply chain optimization with economy objectives such maximize profit and minimize cost, environmental effect and stakeholder satisfaction with the aim to relate the existing optimization methods to empirical research and reveal the conceptual framework. The paper classifies existing research streams and application in tire industry areas with different optimization subject. The results of this study gives outlook which optimization methods are available for supply chain managers and give a conceptual framework in tire industry considering sustainable supply chain factors from economic, environmental and societal effect.
\end{abstract}

Keywords: Supply Chain Optimization, Tire industry, environment, societal.

\section{Introduction}

Today, millions of tires are used each year and with the growing concern about environmental issues in recent years, the problem of used tires disposal has attracted many practitioners and researchers [1]. World demand for tires increase 4.1 percent per year and reach to 3.0 billion units in 2019, according to the U.S. Environmental Protection Agency (EPA) report [4]. Hence tire industry is become an important issues for both academics and practitioners. Supply chain optimization is the application of processes and tools to ensure the optimal operation of a manufacturing and distribution supply chain [5]. It can be observed in the existing study that used of problem statements are generally considered:

- Supply chain optimization considerations with sustainable factors 
- Supply chain optimization considerations without sustainable factors

The goal of this study is to classify existing research streams and application in tire industry areas with different optimization subject. The results of this study gives outlook which optimization methods are available for supply chain managers and give a conceptual framework in tire industry considering sustainable supply chain factors from economic, environmental and societal effect.

\section{State-of-the-art review}

\subsection{Literature selection}

Supply chain in the tire industry is getting more complex today. Variabilities of market demand and supply add to the complexity [7]. Supply chain optimization is the application of processes and tools to ensure the optimal operation of a manufacturing and distribution supply chain [5]. In order to restrict our research, so we focused the typical supply chain optimization that used in tire industry. Reverse logistic and closedloop supply chain have an incremental trend in recent years [10]. The single period mixed integer linear programming (MILP) model considering the uncertainty parameters for closed-loop supply chain proposed [11] in their model also the Multi-echelon reverse logistic network adopted by [13] case study at India use mixed integer nonlinear programming (MINLP) models to maximize profit.

\subsection{Mixed integer linear programming (MILP)}

Mixed Integer Linear Programming (MILP) involves problems in which only some of the variables, $\mathrm{x}_{\mathrm{i}}$ are constrained to be integers, while other variables are allowed to be non-integers. This is why it is called Mixed [14]. A mixed integer linear programming model is designed for the closed-loop supply chain to maximize total profit. The proposed model usually determines the optimum number of distribution, collection, recycling centers and retreading. of products to meet the quality for remanufacturing. In fact, uncertainty is embedded in the optimization model [11].

\subsection{Mixed integer non-liner programming (MINLP)}

Mixed integer nonlinear programming (MINLP) refers to optimization problems with continuous and discrete variables and nonlinear functions in the objective function and/or the constraints [14]. MINLP arise in applications in a wide range of fields, including chemical engineering, finance, and manufacturing. Closed-loop supply chain with MINLP model use to maximize profit adopted by [16]. Meanwhile MINLP model in reverse logistic proposed by [13] to maximize profit in remanufacturing tire. 


\section{$2.4 \quad$ Closed-loop supply chain}

The closed-loop supply chain consists of the activity start from design, control, and operation for a system in terms for maximize value creation over the entire life cycle of a product with the dynamic recovery [8]. Designing an economically and ecologically optimized closed-loop supply chain network is a prerequisite for tire producers to facilitate increased environmental responsibility and sustainable development [3].

Some literature reviews papers have been published about closed-loop supply chain in tire industry such as [3] with minimize environment impact and maximize profit. [2] And [17] with the first stage model on maximize profit but in second stage the model focus on sustainable factors such minimize environment and social effect, maximize profit.

\subsection{Reverse logistic}

Reverse logistics (RL) has been defined as a term that refer to the role of logistics in product returns, the source reduction, a recycling, the materials substitution, a reuse of materials, a waste disposal, and the refurbishing [9]. Reverse logistics systems use of mathematical tools to design for the recovery of products that have ended their life cycle [18]. Beside the MILP or MINLP model for example, in reverse logistics proposed by [9] to minimize the total cost with genetic algorithm also [19] use fuzzy multiobjective mixed integer program model to maximize total profit and coverage area.

\section{Analysis and observations}

\subsection{Literature analysis}

Based on literature analysis on supply chain optimization in tire industry, our next objective is to derive some classifications regarding the following issues:

- What types of supply chain optimization should be considered by supply chain managers.

- Which methods are mostly suitable for supply chain in tire industry.

- How to identify challenges in implementations the supply chain optimization in tire industry.

- What the conceptual framework represents the supply chain implementations in tire industry.

For the first step, identify the implementation of supply chain optimization in tire industry as following Table 1 which describes the methodology, evaluated factor and also research method.

Table 1. Supply chain optimization implementation research in tire industry

\begin{tabular}{llllll}
\hline Authors & Year & Methodology & Evaluated factor & Method & $\begin{array}{l}\text { Research } \\
\text { sector }\end{array}$ \\
\hline [10] Kannan & 2009 & Reverse logistic & $\begin{array}{l}\text { Minimize total supply } \\
\text { chain cost }\end{array}$ & $\begin{array}{l}\text { GA (Genetic algo- } \\
\text { rithm), }\end{array}$ & $\begin{array}{l}\text { Tire, plas- } \\
\text { tic goods }\end{array}$
\end{tabular}




\begin{tabular}{|c|c|c|c|c|c|}
\hline Authors & Year & Methodology & Evaluated factor & Method & $\begin{array}{l}\text { Research } \\
\text { sector }\end{array}$ \\
\hline [3] Subulan & 2015 & $\begin{array}{l}\text { Closed loop } \\
\text { supply chain }\end{array}$ & $\begin{array}{l}\text { Maximize total profit, } \\
\text { minimize total envi- } \\
\text { ronmental impact }\end{array}$ & $\begin{array}{l}\text { MILP (Mixed integer } \\
\text { linear programming), } \\
\text { IFGP }\end{array}$ & Tire \\
\hline $\begin{array}{l}\text { [19] Radhi and } \\
\text { Zhang }\end{array}$ & 2016 & $\begin{array}{l}\text { Closed loop } \\
\text { supply chain }\end{array}$ & Maximize total profit & $\begin{array}{l}\text { MINLP (Mixed inte- } \\
\text { ger nonlinear pro- } \\
\text { gramming) }\end{array}$ & Tire \\
\hline [2] Simic & 2016 & $\begin{array}{l}\text { Closed loop } \\
\text { supply chain }\end{array}$ & Maximize total profit & $\begin{array}{l}\text { Interval parameter } \\
\text { chance constrained } \\
\text { programming model }\end{array}$ & Tire \\
\hline [4] Amin & 2017 & $\begin{array}{l}\text { Closed loop } \\
\text { supply chain }\end{array}$ & Maximize total profit & $\begin{array}{l}\text { MILP (Mixed integer } \\
\text { linear programming) }\end{array}$ & Tire \\
\hline [12] Pedram & 2016 & $\begin{array}{l}\text { Closed loop } \\
\text { supply chain }\end{array}$ & Maximize total profit & $\begin{array}{l}\text { MILP (Mixed integer } \\
\text { linear programming) }\end{array}$ & Tire \\
\hline [20] Simic & 2017 & $\begin{array}{l}\text { Closed loop } \\
\text { supply chain }\end{array}$ & $\begin{array}{l}\text { Maximize total profit, } \\
\text { minimize environment, } \\
\text { social effect }\end{array}$ & $\begin{array}{l}\text { Interval parameter } \\
\text { chance constrained } \\
\text { programming model }\end{array}$ & Tire \\
\hline [21] Yadollahinia & 2018 & Reverse logistic & $\begin{array}{l}\text { Maximize total profit, } \\
\text { maximize customer } \\
\text { satisfaction, minimize } \\
\text { distance collecting fa- } \\
\text { cilities }\end{array}$ & $\begin{array}{l}\text { MILP (Mixed integer } \\
\text { linear programming) }\end{array}$ & Tire \\
\hline [16] Sahedjamnia & 2018 & $\begin{array}{l}\text { Closed loop } \\
\text { supply chain }\end{array}$ & $\begin{array}{l}\text { Minimize total cost, } \\
\text { minimize total envi- } \\
\text { ronmental impact }\end{array}$ & $\begin{array}{l}\text { MILP (Mixed integer } \\
\text { linear programming) }\end{array}$ & Tire \\
\hline [22] Pereira & 2018 & $\begin{array}{l}\text { Closed loop } \\
\text { supply chain }\end{array}$ & $\begin{array}{l}\text { Forecasting volume } \\
\text { scrap tire, probability } \\
\text { of return }\end{array}$ & $\begin{array}{l}\text { FTM (Transfer func- } \\
\text { tion model) }\end{array}$ & Tire \\
\hline [23] Saxena & 2018 & Reverse logistic & $\begin{array}{l}\text { Maximize total profit, } \\
\text { maximize coverage }\end{array}$ & $\begin{array}{l}\text { Fuzzy multi-objective } \\
\text { mixed integer pro- } \\
\text { gramme model }\end{array}$ & $\begin{array}{l}\text { Remanu- } \\
\text { facturing } \\
\text { tire }\end{array}$ \\
\hline [24] Ebrahimi & 2018 & $\begin{array}{l}\text { Closed loop } \\
\text { supply chain }\end{array}$ & $\begin{array}{l}\text { Minimize total cost, } \\
\text { minimize environment } \\
\text { effects, maximize de- } \\
\text { mand responsiveness }\end{array}$ & $\begin{array}{l}\text { Stochastic multi-ob- } \\
\text { jective programming }\end{array}$ & Tire \\
\hline $\begin{array}{l}\text { [13] Fathollahi- } \\
\text { Fard }\end{array}$ & 2018 & $\begin{array}{l}\text { Closed loop } \\
\text { supply chain }\end{array}$ & $\begin{array}{l}\text { Minimize fixed cost, } \\
\text { minimize transporta- } \\
\text { tion cost, minimize } \\
\text { purchasing cost }\end{array}$ & $\begin{array}{l}\text { Tri-level program- } \\
\text { ming model }\end{array}$ & Tire \\
\hline [25] Banguera & 2018 & Reverse logistic & Minimize total cost & $\begin{array}{l}\text { MILP (Mixed integer } \\
\text { linear programming) }\end{array}$ & Tire \\
\hline [26] Costa-Salas & 2017 & $\begin{array}{l}\text { Reverse supply } \\
\text { chain network } \\
\text { design }\end{array}$ & $\begin{array}{l}\text { Maximize economic } \\
\text { benefit, minimize envi- } \\
\text { ronment impact }\end{array}$ & $\begin{array}{l}\text { MILP (Mixed integer } \\
\text { linear programming) }\end{array}$ & Tire \\
\hline [14] Sasikumar & 2010 & Reverse logistic & Maximize profit & $\begin{array}{l}\text { MINLP (Mixed inte- } \\
\text { ger non-linear pro- } \\
\text { gramming) }\end{array}$ & $\begin{array}{l}\text { Remanu- } \\
\text { facturing } \\
\text { tire }\end{array}$ \\
\hline $\begin{array}{l}{[27]} \\
\text { Bhattacharyya }\end{array}$ & 2017 & $\begin{array}{l}\text { Closed loop } \\
\text { supply chain }\end{array}$ & Maximize profit & $\begin{array}{l}\text { MILP (Mixed integer } \\
\text { linear programming) }\end{array}$ & Tire \\
\hline [28] Farias & 2017 & $\begin{array}{l}\text { Supply chain } \\
\text { network design }\end{array}$ & $\begin{array}{l}\text { Minimize fixed cost, } \\
\text { minimize variable cost }\end{array}$ & $\begin{array}{l}\text { MILP (Mixed integer } \\
\text { linear programming) }\end{array}$ & Tire \\
\hline
\end{tabular}




\subsection{Critical analysis}

Publications specifically for tire industry the research of supply chain optimization are boomed in 2015 until present. In early 2010 there are no significant publications as described in Fig.1 summary of supply chain optimization implementation research in tire industry in last decade, also the objective function is analyzed. Mostly the recent publication have evaluate factor in economic sector. Sustainable supply chain factor implementation is still limited.
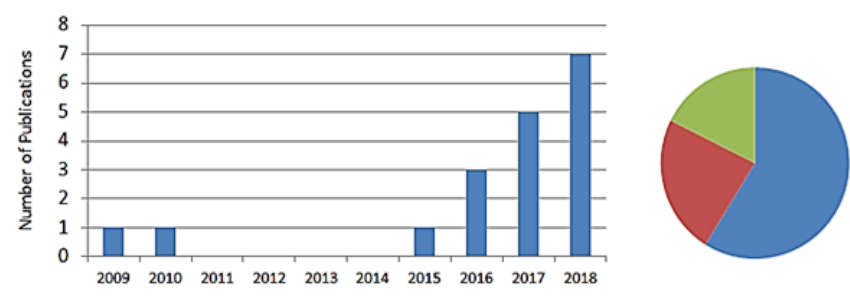

Distribution publication by evaluated factor

घeconomic

घeconomic,environment

a economic,environment, social

Fig. 1. Publication review of supply chain optimization in tire industry

\subsection{Managerial implications}

In many practical settings, companies need analysis tools to estimate both the supply chain robustness and sustainable. For sustainable supply chain the objective function need to consider from economic, environment and social impact. Thus the Table 2 and 3 as the results of classified literature review by objective function categories can contribute to give support decisions reference for supply chain manager in tire industry to implement based on desired objective that match with their company objective.

Table 2. Supply chain optimization classified by objective function

\begin{tabular}{|l|l|l|}
\hline \multicolumn{1}{|c|}{ Economic } & \multicolumn{1}{|c|}{ Economic, Environment } & \multicolumn{1}{|c|}{ Economic, Environment, Social } \\
\hline [10] Kannan, [19] Radhi and Zhang, [2] & [3] Subulan, [16] Sahedjam- & [20] Simic, [21] Yadollahinia, \\
Simic, [4] Amin, [12] Pedram, [13] Fathol- & $\begin{array}{l}\text { nia, [23] Saxena, [26] Costa- } \\
\text { lahi-Fard, [25] Banguera, [14] Sasikumar, } \\
\text { [27] Bhattacharyya, [28] Farias }\end{array}$ & $\begin{array}{l}\text { Salas } \\
\text { [24] Ebrahimi }\end{array}$ \\
\hline
\end{tabular}

Table 3. Matrix managerial implications

\begin{tabular}{|l|l|l|l|l|}
\hline & \multicolumn{1}{|c|}{ Suppliers } & \multicolumn{1}{c|}{ Manufacturer } & \multicolumn{1}{c|}{ Collecting center } & \multicolumn{1}{c|}{ Recycler } \\
\hline Economic & $\begin{array}{l}\text { Optimize raw mate- } \\
\text { rial purchasing }\end{array}$ & $\begin{array}{l}\text { Increase manufacturing } \\
\text { process and capacity, opti- } \\
\text { mize production planning }\end{array}$ & $\begin{array}{l}\text { Optimize distance col- } \\
\text { lecting used / scrap } \\
\text { tires }\end{array}$ & $\begin{array}{l}\text { Optimize plan- } \\
\text { ning recycling / } \\
\text { retreading }\end{array}$ \\
\hline Environment & $\begin{array}{l}\text { Reduce scrap mate- } \\
\text { rials }\end{array}$ & $\begin{array}{l}\text { Minimize return used / } \\
\text { scrap tires }\end{array}$ & $\begin{array}{l}\text { Minimize return } \\
\text { used / scrap tires }\end{array}$ \\
\hline Social & $\begin{array}{l}\text { Increase service } \\
\text { level compliance }\end{array}$ & $\begin{array}{l}\text { Optimize demand fulfil- } \\
\text { ment }\end{array}$ & Labour cost efficiency & $\begin{array}{l}\text { Labour cost effi- } \\
\text { ciency }\end{array}$ \\
\hline
\end{tabular}




\section{Towards a conceptual framework}

The developed conceptual framework is expected to provide general guidance [23] on supply chain optimization in tire industry. Fig. 3 illustrates the conceptual framework that is constructed based on the analysis of the findings in the literature. The framework comprises four elements, which represent the essential features for successful supply chain optimization implementation in the tire industry:

(1) Reliable data support;

(2) Sustainable model;

(3) Reliable solvers; and

(4) Simultaneously implementation

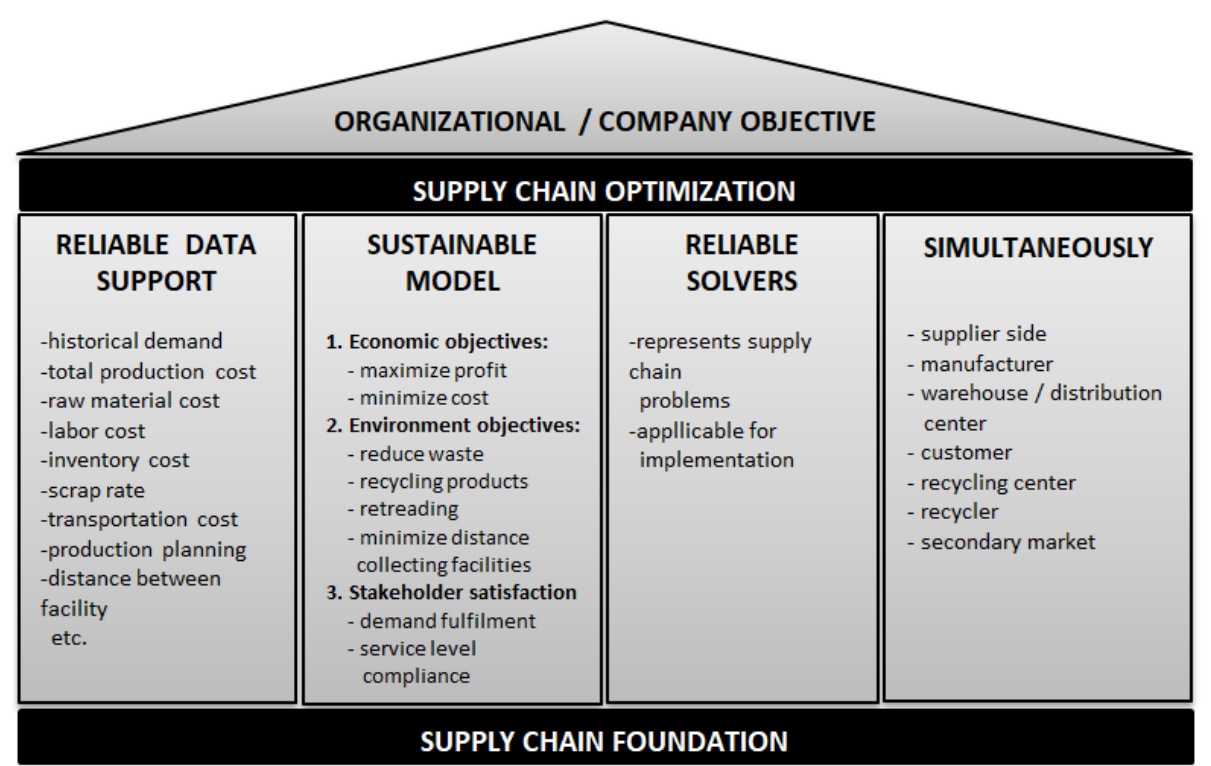

Fig. 2. A conceptual framework for implementing supply chain optimization in tire industry

The contribution from conceptual framework in this manuscript is describing the sustainable supply chain factor that had robust result in the implementation based on literature analysis. Combination of three factors from economic, environment and social impact such provided by [17], [22] and [25] give the robust and sustainable impact in tire industry. Simultaneously factor need to be highlight for supply chain managers in their practical problems to achieve robustness result.

\section{Conclusions}

Supply chain optimization is crucial part to ensure tire business remains profitable and still have a good relation with stakeholder. The managerial implications and conceptual framework for sustainable supply chain optimization such economic, environment, social factor revealed in this study. Thus it is contribute to supply chain manager 
in decision support of their practical problem which the best fit method to achieve the company objective.

Although there is a growing research in supply chain optimization, but still it is limited publications to rise focus on stakeholder satisfaction as the objective of the research. In future, social methodology like customer relationship management need to studied further either in the tire business or in other practical industries.

\section{References}

[1] E. T. Maedeh Yadollahiniaa, "Tire forward and reverse supply chain design considering customer relationship management," Resources, Conservation \& Recycling, no. https://doi.org/10.1016/j.resconrec.2018.07.018, pp. 215-228, 2018.

[2] S. D.-O. Vladimir Simic, "An Interval parameter chance constrained programming model for uncertainty based decision making in tire retreading industry," Journal of Cleaner Production, no. http://dx.doi.org/10.1016/j.jclepro.2016.10.122, pp. 1-9, 2016.

[3] S. T. Kemal Subulan, "The designing an environmentally conscious tire closed loop supply chain network with multiple recovery options using interactive fuzzy goal programming method," Applied Mathematical Modelling, no. http://dx.doi.org/10.1016/j.apm.2014.11.004, pp. 2661-2702, 2015.

[4] G. Z. P. A. Saman Hassanzadeh Amin, "The effects of uncertainty on a closed loop supply chain tire network," Expert Systems With Applications, no. doi:10.1016/j.eswa.2016.12.024, 2017.

[5] S.-c. optimization, "Wikipedia," Wikimedia Foundation, Inc., 09 Feb 2019. [Online]. Available: https://en.wikipedia.org/wiki/Supply-chain_optimization.

[6] C. B.Tjahjono, "What does Industry 4.0 mean to Supply Chain?," Manufacturing Engineering Society International Conference 2017, no. https://doi.org/10.1016/j.promfg.2017.09.191, pp. 2351-9789, 2017.

[7] M. Kartika N. Alfina, "Optimization Supply Chain Strategy of Tire Manufacturing using Goal Programming Method," SSRN eLibrary, no. http://dx.doi.org/10.2139/ssrn.3248155, 2018.

[8] J. L. N. V. W. V. Daniel R. Guide, "The Evolution of Closed-Loop Supply Chain Research," Institute for Operations Research and the Management Sciences (INFORMS), no. DOI 10.1287/opre.1080.0628, pp. 10-18, 2009.

[9] A. N. H. M. D. G. Kannan, "The analysis of closed loop supply chain using genetic algorithm and particle swarm optimisation method," International Journal of Production Research, vol. 47, no. http://dx.doi.org/10.1080/00207540701543585, p. 1175-1200, 2009.

[10] H. S. Kannan Govindan, "The review of Reverse Logistics and Closed Loop Supply Chains for Cleaner Production Focus," Journal of Cleaner Production, no. DOI:10.1016/j.jclepro.2016.03.126, 2017.

[11] N. B. Y. O. E. U. Ali Pedram, "Integrated forward and reverse supply chain: A tire case study," Waste Management, no. http://dx.doi.org/10.1016/j.wasman.2016.06.029, 2016.

[12] M. H.-K. S. M. Amir Mohammad Fathollahi-Fard, "Hybrid optimizers to solve a trilevel programming model for a tire closed-loop supply chain network design problem," Applied soft computing, no. https://doi.org/10.1016/j.asoc.2018.06.021, 2018. 
[13] G. K. A. N. H. P. Sasikumar, "A multi-echelon reverse logistics network design for product recovery - a case of truck tire remanufacturing," International Journal Advance Manufacturing Technology, no. DOI 10.1007/s00170-009-2470-4, p. 12231234, 2010.

[14] R. Gate, "Research Gate - MILP, MIP and ILP," 7 July 2017. [Online]. Available: https://www.researchgate.net. [Accessed May 2019].

[15] A. M. F. F. Navid Sahebjamnia, "Sustainable tire closed-loop supply chain network design: Hybrid metaheuristic algorithms for large-scale networks," Journal of Cleaner Production, vol. 196, no. https://doi.org/10.1016/j.jclepro.2018.05.245, pp. 273-296, 2018.

[16] G. Z. Mohannad Radhi, "Optimal configuration of remanufacturing supply network with return quality decision," International Journal of Production Research, no. http://dx.doi.org/10.1080/00207543.2015.1086034, 2015.

[17] S. D.-O. N. B. Vladimir Simić, "Interval-parameter semi-infinite programming model for used tire management and planning under uncertainty," Computers \& Industrial Engineering, no. http://dx.doi.org/10.1016/j.cie.2017.09.013, 2017.

[18] J. M. S. R. T. M. V. Ó. C. V. Leonardo A. Banguera, "Reverse logistics network design under extended producer responsibility: The case of out-of-use tires in the Gran Santiago city of Chile," International journal of production economics, no. 10.1016/j.ijpe.2018.09.006, 2018.

[19] P. K. J. A. K. S. Lokesh Kumar Saxena, "A fuzzy goal programme with carbon tax policy for Brownfield Tyre remanufacturing," Journal of cleaner production, no. 10.1016/j.jclepro.2018.07.005, 2018.

[20] R. T. W. Jane Webster, "Analyzing the past to prepare for the future : Writing a literature review," MIS Quarterly, vol. Vol. 26, no. 2, 2002.

[21] A. Fink, Conducting research literature reviews from internet to paper, Los Angeles: SAGE, 2014.

[22] E. T. M. M. P. Maedeh Yadollahinia, "Tire forward and reverse supply chain design considering customer relationship management," Resources, Conservation \& Recycling, no. https://doi.org/10.1016/j.resconrec.2018.07.018, pp. 215-228, 2018.

[23] R. C. R. Andika Rachman, "Adoption and implementation potential of the lean concept in the petroleum industry: state-of-the-art," International Journal of Lean Six Sigma, no. https://doi.org/10.1108/IJLSS-10-2016-0065, 2018.

[24] J. Meredith, "Theory building through conceptual methods," International Journal of Operations, vol. 13, no. 5, pp. 3-11, 1993.

[25] S. B. Ebrahimi, "A stochastic multi-objective location-allocation-routing problem for tire supply chain considering sustainability aspects and quantity discounts," Journal of cleaner production, no. 10.1016/j.jclepro.2018.07.059, 2018.

[26] P. V. P. K. Rupesh Kumar Pati, "Quantifying bullwhip effect in a closed loop supply chain," Operational Research Society of India, no. DOI 10.1007/s12597-010-0024-z, p. 231-253, 2011.

[27] K. G. S. Z. Mohd Rizaimy Shaharudin, "Product Return Management: Linking Product Returns, Closed-Loop Supply Chain Activities and the Effectiveness of the Reverse Supply Chains," Journal of Cleaner Production, no. DOI: 10.1016/j.jclepro.2017.02.133, 2017.

[28] G. K. P. Sasikumar, "The multi echelon of reverse logistics network design for product recovery truck tire remanufacturing," Int J Adv Manuf Technol, no. DOI $10.1007 / \mathrm{s} 00170-009-2470-4$, p. 1223-1234, 2010. 